\title{
Az online edzésekben rejlő lehetőségek a fitneszedzők szempontjából
}

\section{The Potential of Online Workouts for Fitness Trainers}

\author{
BARTHA É. J. ${ }^{1}$, SZALÁNCZI Z. ${ }^{2}$ \\ 1University of Debrecen, Faculty of Economics and Sportmanagement; bartha.eva.judit@econ.unideb.hu \\ ${ }^{2}$ University of Debrecen, Faculty of Economics and Sportmanagement; szalanczi.zoltan@econ.unideb.hu
}

\begin{abstract}
Absztrakt. A fizikai aktivitás jelentősége mind a fizikai, mind a mentális egészség szempontjából megkérdőjelezhetetlen. A szabadidő sportolók számára a mindennapos edzések közkedvelt helyszínének tekinthetők a fitnesztermek, és nagy népszerüségnek örvendenek a szakképzett edzók által irányított órák, akár személyi akár csoportos edzésekről van szó. A világszerte megfigyelhető trendnek megfelelöen a fitnesz edzésekkel szemben is növekvő elvárás, hogy minél egyszerúbben, minél több formában, a kötött helyszínektôl függetlenül is lebonyolithatók legyenek. Vizsgálatunk célkitüzése ezért az, hogy feltérképezzük, mennyire jellemző az online edzések elterjedtsége a fitnesz szektorban dolgozó edzők körében. Az ilyen edzések iránt jelentôs igény mutatkozik meg, még ha nem is válthatja fel teljesen a személyes jelenléttel zajló órákat. Kiegészítésként, valamint olyan célcsoportoknak, akiknek fontos, hogy bárhol, bármikor végezhetô mozgásformát találjanak, ideális lehetőséget nyújt az online tér a rendszeres fizikai aktivitás gyakorlására, valamint az edzők számára is jó lehetőség arra, hogy bővítsék vendégkörüket, szolgáltatásaikat.
\end{abstract}

The importance of physical activity for both physical and mental health is unquestionable. For leisure athletes, fitness clubs can be considered as popular facilities for everyday workouts. Classes run by qualified trainers, whether individual or group workouts, are very popular. In line with the worldwide trend, there is a growing expectation for fitness workouts to be reachable as simple as possible, in as many forms as possible, regardless of the location. The aim of our study is therefore to map the prevalence of online training among trainers working in the fitness sector. There is a significant demand for such workouts, even if it cannot completely replace hours of personal presence. In addition, as well as for target groups who want to find a form of exercise that can be performed anywhere, anytime, the online space provides an ideal opportunity to practice regular physical activity, as well as a good opportunity for coaches to expand their clientele and services.

Kulcsszavak: fitnesz szektor, fitneszedzók, fitnesz fogyasztók, online edzések

Keywords: fitness segment, fitness trainers, fitness consumers, online workouts

\section{Bevezetés}

A fitnesz szektor sportlétesítményei, azaz a fitnesztermek napjainkra az egészségtudatos magatartás megvalósulásának kiemelten fontos helyszíneivé váltak. Az utóbbi évtizedben a fitneszteremben edző vendégek száma világszerte 72\%-os növekedést mutatott, ami azt jelenti, hogy az Európai Unió lakosai 
közül megközelítőleg 65 millióan edzettek rendszeresen fitnesztermi környezetben [1]. Ez a tendencia azonban a 2020-as intézkedések következtében megtorpant a járványügyi helyzetnek köszönhetően. Ez az év a gazdaság számos szereplője mellett nagy hatással volt a fitneszklubokra is, amelyek jelenleg zárva vannak a szélesebb közönség előtt, egy évvel a lezárások kezdete után is. Az edzőtermek látogatói, tehát európaszerte több, mint 60 millió ember, így más helyszínen kénytelenek folytatni rendszeres testmozgásukat, amennyiben nem áll szándékukban felhagyni a sportolással.

Az online edzések bizonyos formái már régóta rendelkezésére állnak az érdeklődőknek, azonban most talán még nagyobb a szerepük az egészségmegőrzésben, és ezt az egészség- és fitnesziparnak is szem előtt kell tartani a jövőbeni fejlődés és növekedés érdekében. Az online edzések iránti kereslet robbanásszerű növekedésének köszönhetően, az ACSM előrejelzései alapján ezek számítanak 2021 legmeghatározóbb trendjének. Ezt nem csak a szolgáltatóknak érdemes szem előtt tartani, hanem a fitnesz szektorban dolgozó szakembereknek is. A fitneszklubokban alkalmazott, szabadidő sportolókkal foglalkozó edzők számára az online tér egy jó lehetőséget teremt arra, hogy a hozzájuk járó vendégekkel folytatni tudják a közös munkát, akár az edzőtermi lehetőségekhez képest rugalmasabb keretek között is, hiszen az online megtartott edzéseket nem befolyásolják olyan külső körülmények (helyszíntől való távolság, nem megfelelő időjárás), amelyek a fitneszklubokban vagy a szabadban folytatott testmozgást esetleg akadályoznák.

Vizsgálatunk fő célkitűzése az volt, hogy feltárjuk, milyen típusú online edzések léteznek és melyek ezek közül a legnépszerűbbek a fitnesz szektor szereplői körében. Kutatásunk arra is kiterjedt, hogy mennyire élnek az online eszközök nyújtotta lehetőségekkel a fitneszedzők, és melyek az általuk leggyakrabban alkalmazott eszközök.

\section{Fitnesz trendek}

A sport szerepének növekedése nem csak az emberek életmódjában, életstílusában jelenik meg, hanem fogyasztói és vásárlási szokásaikat is befolyásolja. A sport és a sportfogyasztás területén zajló közép- és hosszútávú folyamatokkal, változásokkal a trendkutatás foglalkozik [2].

A trend kifejezés valamilyen irányvonalat, irányzatot jelölt, megmutatja, hogy egy adott időszakban milyen termékek, szolgáltatások számítanak népszerűnek. A fitnesztrendek a fitnesz szektoron belül jellemző aktuális divatot mutatják meg [3].

A trendek lehetnek reverzibilisek illetve irreverzibilisek, ciklikusak és aciklikusak, és növelhetik vagy csökkenthetik a stabilitást [4].

A trendek között megkülönböztethetünk megatrendeket és aktuális trendeket is. A sportfogyasztási szokásokkal kapcsolatban legtöbbször a hosszútávú (mega)trendeket, valamint a középtávú trendek és ellentrendek hatásait érdemes vizsgálni [5]. Vannak azonban olyan történések, amelyek előre nem kiszámíthatók, váratlanul jelentkeznek és jelentős tömeghatást idéznek elő. Ezeket Taleb (2012) „fekete hattyú" jelenségeknek nevezi, és ide sorolhatjuk a Covid19 megjelenését is világszerte, amely a fitneszipart is kihívások elé állította [5].

Az American College of Sports Medicine (ACSM) minden évben a fitneszipar több ezer szakértőjével együttműködve vizsgálja a fitnesz szektorban legmeghatározóbb trendek alakulását. 
A pre-covid időkben tehát a három legnépszerűbb fitnesz trendnek a „hordható technológia”, a HIIT edzések valamint a csoportos edzések számítottak. A tíz legnépszerűbb trend között megjelentek a funkcionális edzések, megjelent a mozgásgyógyszer szemlélet és az idősebbeknek szóló fitnesz edzések is, látható tehát, hogy a fitneszipar által nyújtott szolgáltatások köre, és ezzel párhuzamosan a megcélzott fogyasztói csoportok is egyre bővülnek ebben a szektorban. A fitneszklubok, amelyekkel kapcsolatban számos előítélet terjedt, amelyek szerint csak a tömegnövelőket és tiltott táplálékkiegészítő és teljesítményfokozó szereket használó, hatalmas izomtömeggel rendelkező testépítők járnak ezekbe az edzőtermekbe, évek alatt az egészséges életmód minden korosztály számára elérhető helyszínévé váltak. A dinamikus növekedést azonban átmenetileg megállította a 2019-ben világszerte kialakult járványhelyzet.

Felnőttek millióit érintette a COVID-19-hez kapcsolódó fitneszlétesítmények bezárása ebben és az előző évben, akik így arra kényszerültek, hogy innovatív és otthon is végezhető módjait találják meg a rendszeres sporttevékenységnek. Ennek tükrében nem meglepő, hogy az Amerikai Sportorvosi Szövetség (ACSM) által megkérdezett egészségügyi és fitnesz szakemberek előrejelzései alapján az online edzés lett a 2021-es év új és legmeghatározóbb fitnesz trendje. Ezzel az online edzés 2020-hoz képest 25 helyet ugrott előre a legnépszerübb trendek rangsorában [6]. A 2021-es év legjelentősebb trendjeit az 1. táblázat mutatja be.

\begin{tabular}{|l|}
\hline \multicolumn{1}{|c|}{2021 FITNESZ TRENDJEI } \\
\hline 1. ONLINE EDZÉS \\
\hline 2. Hordható technológia \\
\hline 3. Saját testsúlyos edzés \\
\hline 4. Szabadtéri edzések \\
\hline 5. HIIT \\
\hline 6. Virtuális edzés \\
\hline 7. Mozgásgyógyszer \\
\hline 8. Erősítő edzés szabd súlyokkal \\
\hline 9. Fitnesz edzés időseknek \\
\hline 10. Személyi edzés \\
\hline
\end{tabular}

\section{1. táblázat: A 2021. év fitnesz trendjei}

Forrás: Saját szerkesztés ACSM (2021) alapján [6]

2021-ben az előtte lévő évekhez képest jelentősen átrendeződött az élvonal a fitnesz trendek között. 2016 óta a hordható technológia és a HIIT edzések mindig az első három hely valamelyikén szerepeltek, 2021-ben azonban rögtön az élre kerültek az online edzések, amelyek világszerte a legmeghatározóbb trendnek számítanak. 


\section{Anyag és módszer}

Kutatásunkhoz a kérdőíves megkérdezés módszerét választottuk. A kérdőíveket online formában juttattuk el a megkérdezettekhez. A kutatás céljáról valamint a kitöltés anonimitásáról tájékoztattuk a kitöltőket a válaszadási hajlandóság növelése céljából [7]

A kérdőív tartalmazott a demográfiai adatokra vonatkozó kérdéseket (nem, életkor, lakóhely, anyagi helyzet), emellett felmérte, hogy a válaszadók milyen formában tartottak a járványhelyzet miatti lezárások előtt fitnesz edzéseket, valamint, hogy a lezárások óta milyen formában tartják ezeket. Tartalmazott kérdéseket arra vonatkozóan, hogy milyen formáit ismerik az online edzéseknek és ezek közül melyek azok, amelyeket előszeretettel alkalmaznak. Megkérdeztük azt is, tervezik-e a jövőben folytatni az edzések ezen formáját a személyes jelenléttel zajló órák mellett is.

Olyan edzők kitöltését kértük, akik fitneszedzéseket tartanak, és akiknek vannak ismereteik vagy tapasztalatuk az online edzéslehetőségekről. 114 fitneszedző válaszolt kérdéseinkre. A kérdőívet kitöltő fitneszedzők körében a nők aránya sokkal magasabb, mint a férfiaké. A kérdésekre összesen 42 férfi és 72 nő válaszolt (1. ábra).

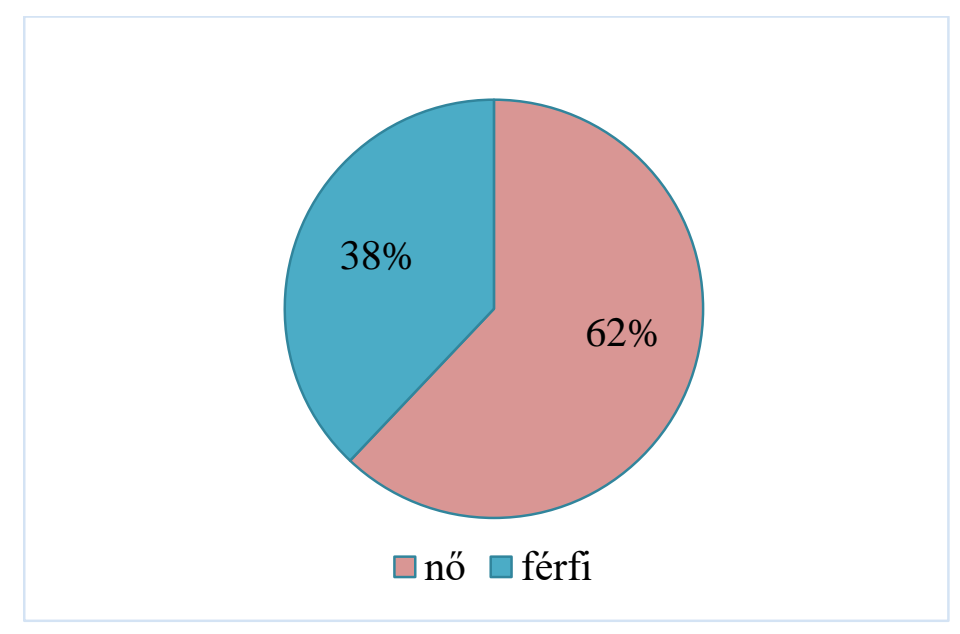

\section{1. ábra: Az edzối minta nemek szerinti megoszlása}

Forrás: Saját kutatás, 2021.

A következő demográfiai jellemző, amelyet vizsgáltunk a válaszadó edzők körében, az életkor volt. A válaszokat a 2. ábra szemlélteti. 


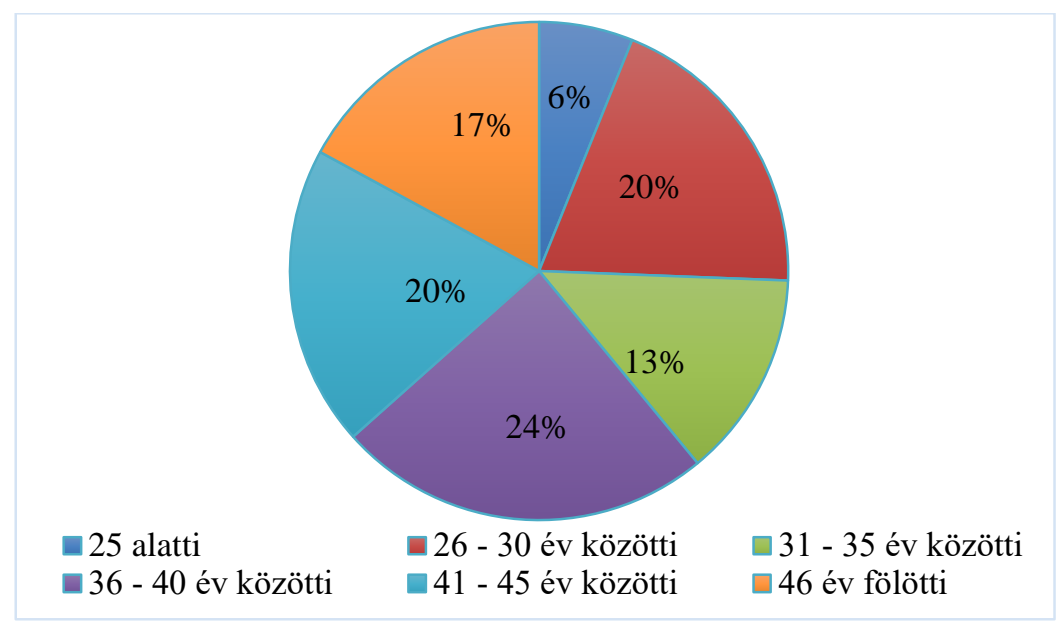

\section{2. ábra: Az edzői minta életkor szerinti megoszlása}

Forrás: Saját kutatás, 2021

Lakóhely tekintetében a válaszok eloszlása szintén kiegyensúlyozott volt, a minta 33\%-a a fôvárosban él, 40\%-a megyeszékhelyen, míg 27\%-a egyéb városban, nem volt olyan kitöltő, aki arról számolt volna be, hogy kisebb településen lakik.

\section{A vizsgálat eredményei}

A demográfiai adatokat követően azt vizsgáltuk, hogy módosultak-e, és ha igen, hogyan a fitneszedzők edzéstartási szokásai. Elsőként felmértük, hogy a fitneszklubok bezárása előtt milyen helyszínen, milyen formában tartották edzéseiket (3. ábra).

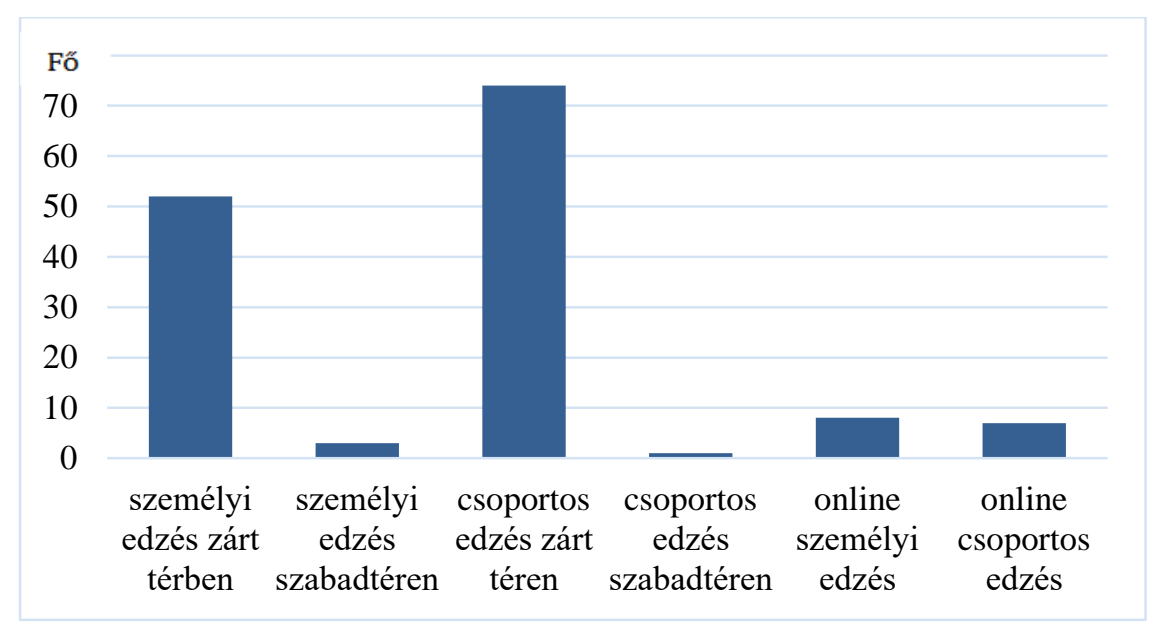

3. ábra: Edzéstartás formái a lezárások elōtt

Forrás: Saját kutatás, 2021 
Az eredmények alapján megállapítható, hogy a fitneszedzői mintában a fitnesztermi csoportos edzéseket tartó szakemberek vannak többségben (51\%) a személyi edzésekhez képest (36\%). A csoportos és a személyi edzések terén is a fitneszteremben tartott órák a leggyakoribbak, azonban néhányan már a lezárások előtt is tartottak online személyi edzést (5\%) és online csoportos edzést (5\%). A szabadtéri edzések elterjedtsége a válaszadók között nem jellemző, mindössze 2\%-uk számolt be arról, hogy személyi edzéseket és 1\%-uk arról, hogy kinti csoportos órákat tartott a lezárásokat megelőzően.

Feltételezhetően a fitneszedzők kihasználják a fitnesz szolgáltatók által nyújtott előnyöket, többek között a jó infrastruktúrát, az időjárási körülmények okozta akadályok kiküszöbölését, a kényelmes és kiszámítható szolgáltatásokat, amelyeket egy sportlétesítmény biztosít.

Ezután felmértük azt, hogy mennyiben módosította a fitnesztermek bezárása ezeket a szokásokat, hogyan oldják meg azóta az edzők az edzéstartás folytatását. Nem meglepő, hogy a válaszok megoszlása jelentősen átalakult. Az edzők nagy része fitneszteremben dolgozik, és valószínűleg előtte inkább elvétve tartott alternatív helyszíneken edzéseket, esetleg azért, mert anyagilag jobban megérte, vagy annak érdekében, hogy színesítse kínálatát a vendégek preferenciáinak megfelelően. A 4. ábrán azonban láthatjuk, hogy a válaszadók körében a fitnesztermi edzések, amik a lezárások előtt a leggyakoribbak voltak, jelentősen csökkentek.

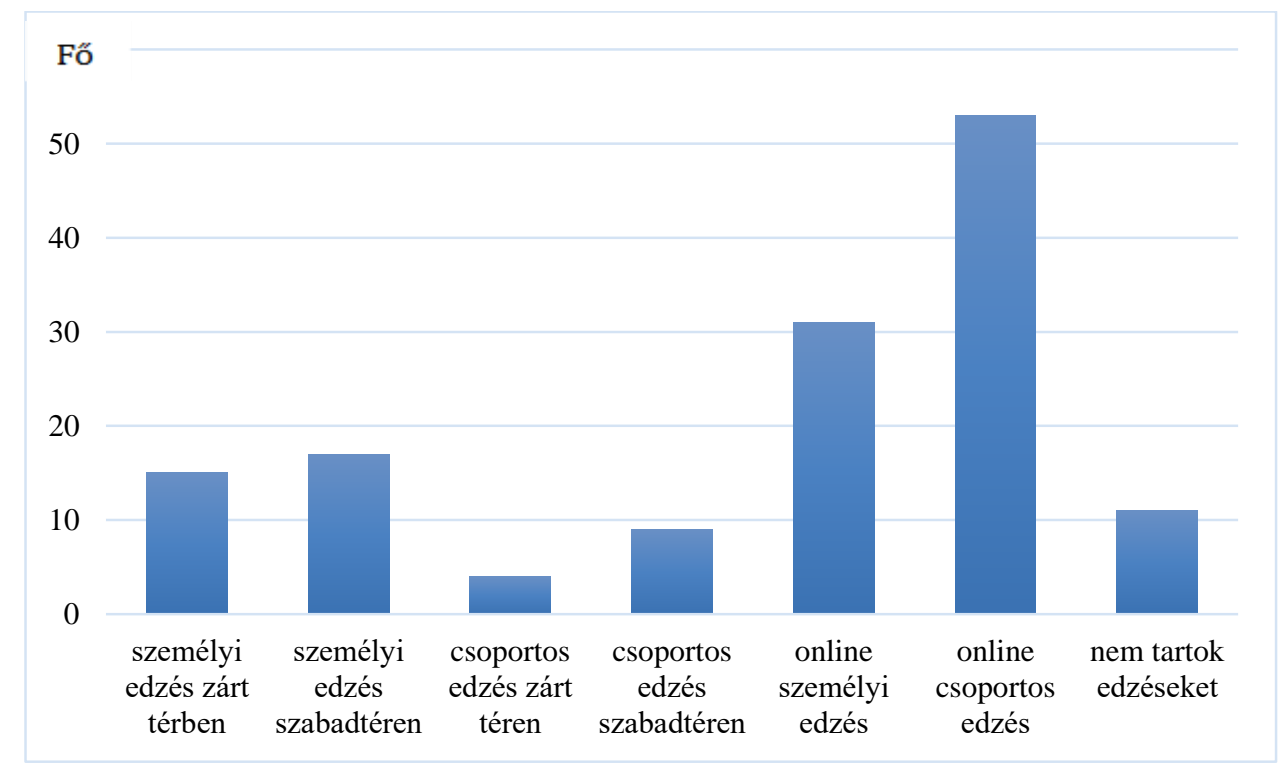

4. ábra: Edzéstartás formái a lezárások óta

Forrás: Saját kutatás, 2021 
Az eredményekből egyértelműen látható, hogy a járványhelyzet hazánkban jelentősen átalakította a fitneszedzések megszokott módjait is. A legelterjedtebb formája az edzők körében ebben az időszakban az online csoportos edzés lett (38\%), ezt követi az online személyi edzés (22\%). Vannak, akik továbbra is tartanak személyi edzéseket (11\%) és csoportos edzéseket (3\%) zárt térben. Ami szembeötlő eredmény, hogy megnőtt a szabadtéri edzések száma, a minta 12\%-a személyi, $6 \%$-a pedig csoportos edzéseket tart szabadtéri helyszínen. Ez azért jelentős eredmény, mert a kinti edzéseknek hazánkban eddig nem volt olyan széles közönsége, Kovács et al. 2015-ös kutatása szerint leginkább az otthoni edzéseket preferálják a magyarok [8]. Emellett a fitneszklubok edzéseinek látogatottsága is növekedő tendenciát mutat az utóbbi években. A járványügyi korlátozások miatt azonban az edzőknek más lehetőségeket kell elérhetővé tennie egyrészt azért, hogy a sportolók fizikai aktivitása megmaradjon, másrészt azért, hogy saját megélhetésüket biztosítsák. Erre jelenthetnek megfelelő megoldást mind a szabadtéri edzések, mind az online edzések különböző formái.

Az eredmények is alátámasztják feltételezésünket, amely szerint az online edzések egy lehetséges alternatívát jelenthetnek a fitneszedzők számára, amely segítségével megtarthatják vendégkörüket és bevételre tehetnek szert. Így vizsgálatunk következő lépéseként az online edzésekkel kapcsolatos ismereteit, tapasztalatait mértük fel az edzőknek.

Az online edzéseknek több formája is létezik, amelyekből minden edző kiválaszthatja a számára legszimpatikusabbat. Azt, hogy ki melyiket preferálja, befolyásolhatja az edző személyisége, képességei, valamint a hozzá járó szabadidő sportolók elvárásai, preferenciái is. Első kérdésünk az online edzésekkel kapcsolatban arra vonatkozott, hogy mennyire ismerik ezek különböző formáit a válaszadó fitneszedzők. Az eredmények a 5. ábrán láthatók.

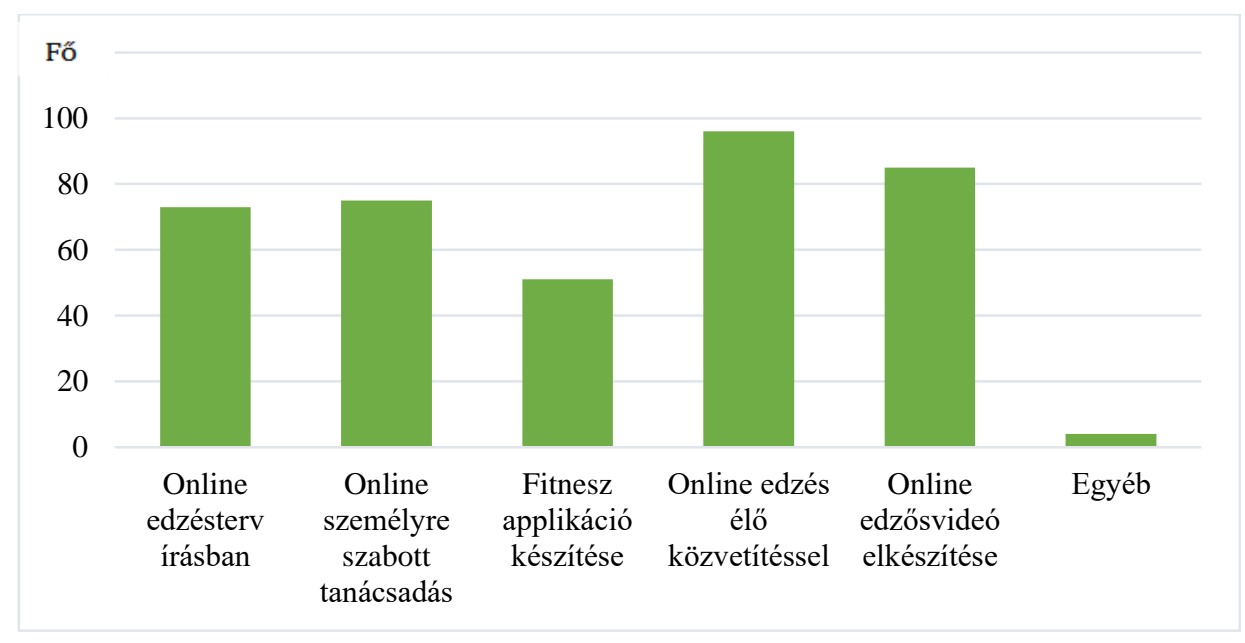

\section{5. ábra: Online edzésmódok ismertsége az edzők körében}

Forrás: Saját kutatás, 2021 
Az ábrán megfigyelhető, hogy valamennyi online lehetőség ismertnek számít a fitneszedzők körében. A válaszadók 75\%-a hallott már az online edzéstervek írásban történő továbbításának lehetőségéről, 76\%-a az online tanácsadásról, 98\%-a az élő videón közvetített edzésekről, 87\%-a az edzős videók felvételéről és elérhetővé tételéről, 52\%-uk pedig a fitnesz applikációk készítéséről is. Összesen 4 válaszadó jelölte meg az egyéb lehetőséget, amelyből hárman a képekkel illusztrált edzéstervet nevezték meg, mint általuk ismert online módszert.

Nem véletlen, hogy a fitneszedzők ismereti kiterjednek a kérdőívben felsorolt összes módszerre. Napjainkban az internetről való információszerzés meglehetősen elterjedt, a közösségi oldalak számítanak szinte a legszélesebb körökben alkalmazott ismeretgyűjtési forrásnak. Ezeken jelentős mennyiségben találhatnak az edzők érdeklődési körüknek megfelelő tartalmakat a fent említett formákban $[9,10]$. Így amikor tudásukat az interneten elsajátítható ismeretekkel bővítik, ezeknek az eszközöknek bármelyikét alkalmazhatják. Kérdőívünk következő kérdése ezért arra vonatkozott, hogy ezek közül melyik az a módszer, amelyet próbáltak is már a kitöltők.

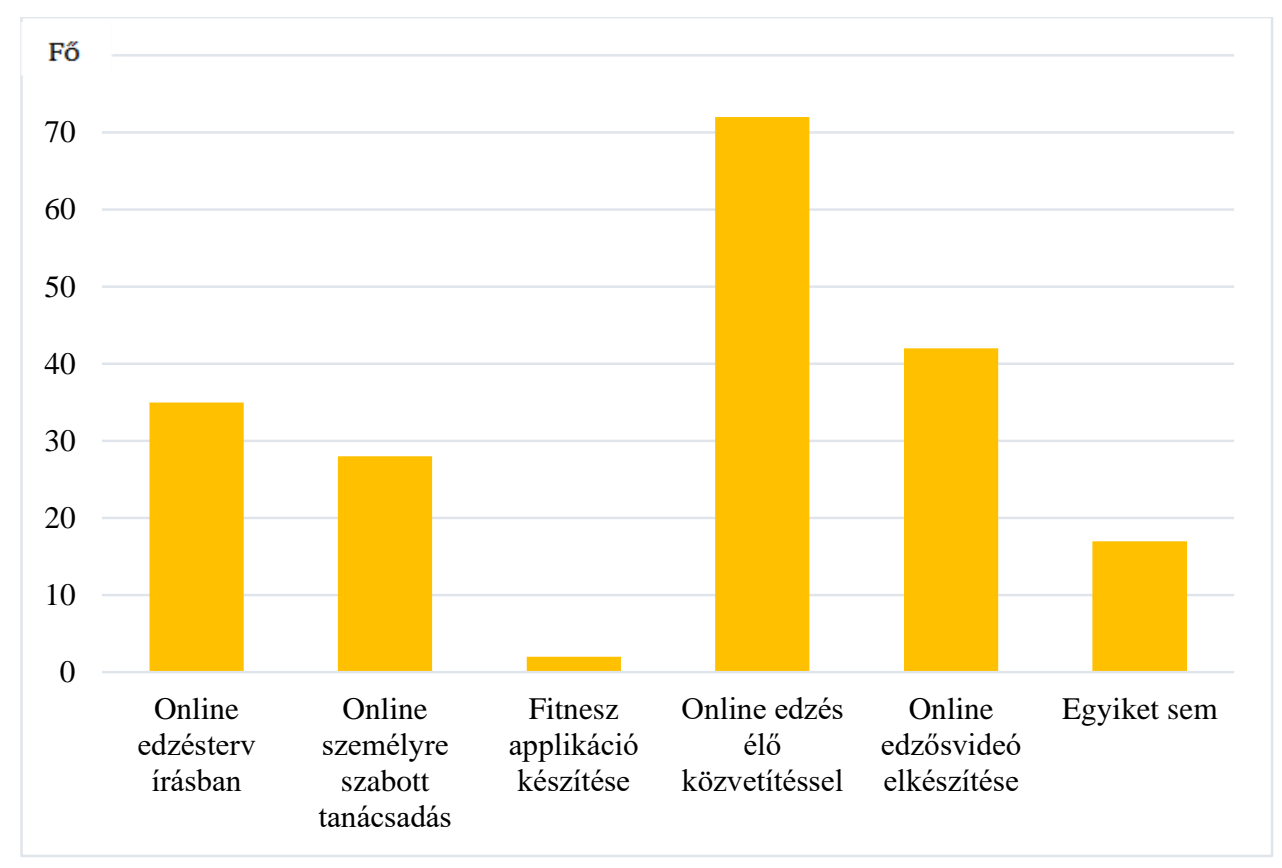

6. ábra: Online edzésmódok alkalmazása az edzők körében

Forrás: Saját kutatás, 2021

A 6. ábra bemutatja, hogy az online edzésmódok közül melyek azok, amelyeket a mintát alkotó edzők alkalmaztak már edzéseik során. Látható, hogy legnépszerűbbnek az összes közül az élő közvetítéses edzéstartás számít, amelyet a megkérdezettek 37\%-a használt már munkája során. Ennek népszerűségét eredményezheti az, hogy egy élő közvetítés közben és után is egyszerűen nyomon követhető, hogy kik tekintették meg a felvételt, és interaktív is, hiszen attól függően, hogy milyen 
platformon zajlik a közvetítés, az edzés résztvevői is tudnak akár webkamerán keresztül képpel és hanggal, akár írásban kommunikálni edzőjükkel. További előnye még az élő közvetítésnek, hogy amennyiben a résztvevők is képpel jelentkeznek be az edzésre, az edzőjüknek lehetősége van szemmel tartani a gyakorlatok szabályos technikai kivitelezését és javítani az esetleges hibákat.

A következő leggyakrabban alkalmazott módszer a mintában az edzős videók készítése volt, amelyet a kitöltők 21\%-a próbált már ki. Ennek egyik nagy előnye valószínűleg az, hogy az edzős videó időben akár korlátlanul is hozzáférhető lehet. Míg az élő edzéseket egy meghatározott időintervallumban lehet követni, ugyanúgy, mint az edzőteremben a kijelölt órarendnek megfelelően, addig a videókat a feltöltés után legtöbbször bármilyen időpontban meg lehet tekinteni, le lehet tölteni függetlenül attól, hogy kelle érte fizetni. Ezeket a módszereket követte az online edzésterv elkészítése és írásban való elküldése (18\%), valamint az online személyre szabott tanácsadás (16\%), amelyek feltehetően inkább a személyi edzésre járó vendégeknél játszanak nagyobb szerepet, hiszen azok a sportolók, akik a csoportos edzéseket preferálják, vélhetően szívesebben részt vesznek online is olyan edzéseken, ahol lehetőségük nyílik arra, hogy a megszokott társasággal, közben velük folyamatos kapcsolatot tartva sportolhassanak, mint például az élő közvetítések során.

A fitnesz applikációk készítése egyáltalán nem jellemző a mintában, összesen két fitneszedző számolt be arról, hogy alkalmazott már ilyet munkája során. Ennek lehet az oka maga az applikáció készítésének bonyolultsága, az informatikai ismeretek hiánya, vagy esetleg a vendégkör nem igényli ezt a fajta módszert. Fontos felhívni a figyelmet arra, hogy az edzők 9\%-a úgy nyilatkozott, hogy nem tartanak edzéseket, mióta nincsenek nyitva az edzőtermek. Ennek lehet az az oka, hogy más munkával biztosítják megélhetésüket, lehet, hogy nincs rá olyan igény az edzésre járók irányából, hogy megérje megtartani az órákat, de akár az is előfordulhat, hogy eszközigényes edzésről van szó, ami online keretek között nehezebben megvalósítható akár az edző, akár a vendégek részéről (pl. nem rendelkeznek spinning kerékpárral, TRX-szel, hot iron felszereléssel).

Az edzők nagy része tehát (mindössze 9\% a kivétel) sikeresen átállt az online edzéstartásra a járvány okozta korlátozások következtében. Eredményeink azt tükrözik, hogy tájékozottak az online eszközök alkalmazásával kapcsolatban, és sokan ki is választották a számukra legmegfelelőbbet. Kutatásunkban azt is felmértük, hogy vajon szándékában áll-e a válaszadóknak az új, online módszerek alkalmazása a későbbiekben is, amikor már lesz lehetőségük személyesen is edzést tartani sportolóiknak.

A 7. ábrán látható, hogy a válaszadók nagy részének a fitnesztermek újranyitása után is tervei között szerepel az online edzések megtartása repertoárjukban (online személyi edzés 17\% és online csoportos edzés $14 \%$ ) a személyes jelenléttel tartott edzések mellett is. 


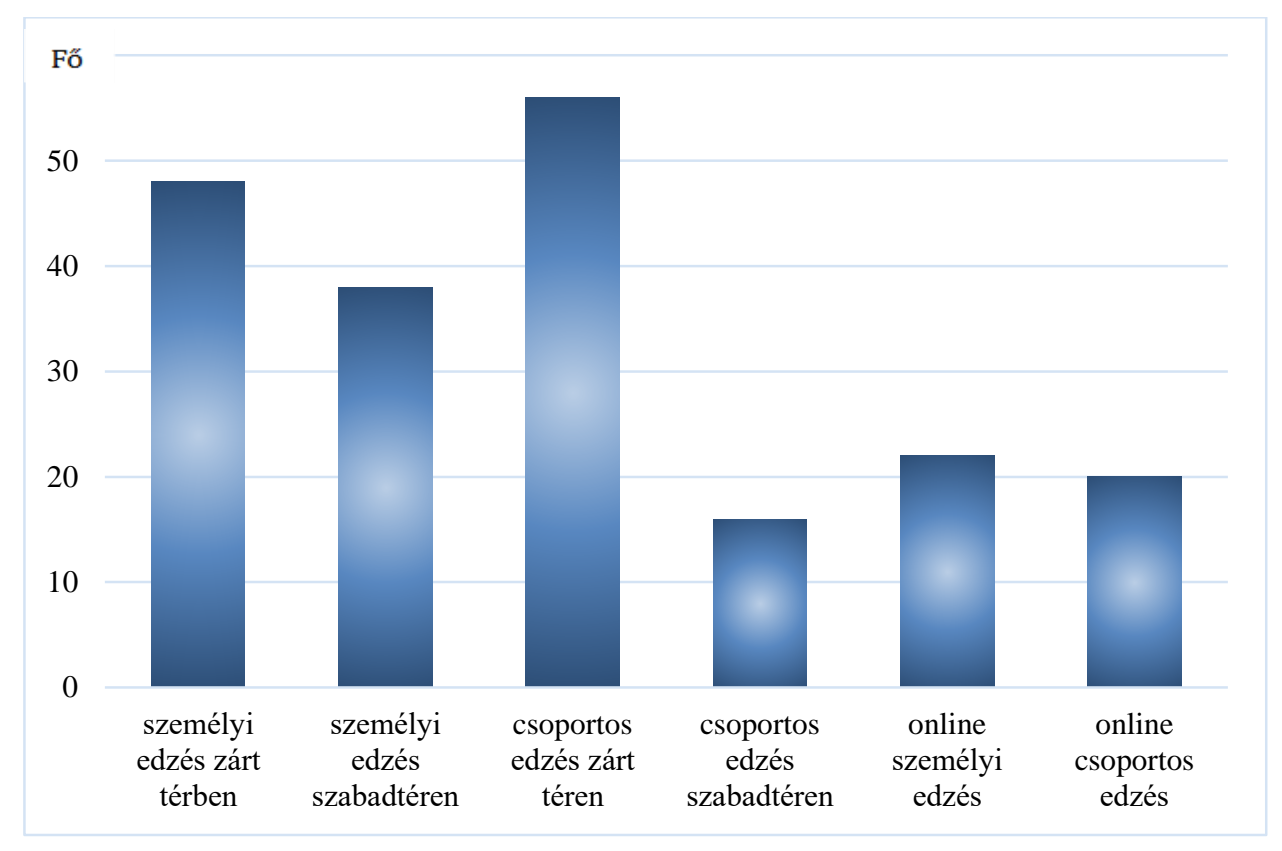

7. ábra: Az edzők tervei a fitnesztermek kinyitása után

Forrás: Saját kutatás, 2021

Emellett meg kell jegyezni azt is, hogy szemmel láthatóan nyitottabbá váltak az edzők a szabadtéri edzések tartása iránt is, hiszen a lezárások előtt sokkal kisebb számban tartottak kültéri személyi és csoportos órákat a válaszadók, mint ahányan tervezik (19\%) a fitneszklubok nyitása utáni időszakban is.

Ezek az eredmények arra engednek következtetni, hogy vannak előnyei is a fitnesztermek ideiglenes bezárásának, hiszen olyan edzéstartási lehetőségeket próbáltak ki (még ha eleinte csak kényszerből is) a fitneszedzők, amelyeket - feltételezhetően számos előnyüket megtapasztalva- a továbbiakban is szívesen megtartanak szolgáltatásaik között.

\section{4. Összegzés}

Az egészséges életmóddal, edzésekkel kapcsolatban csak úgy, mint a más területeken történő információszerzés esetében, az ismeretek megszerzésének legfőbb felületévé az online oldalak, ezen belül is a közösségi média platformjai váltak. Az egészségműveltség elsajátításának főként a fiatalok körében mindennapi forrásai lettek a különböző közösségi oldalak. Ez az egyik fő tendencia, amely arra enged következtetni, hogy az online sportolási lehetőségeknek van létjogosultsága hosszú távon is, hiszen az információszerzés módjának ilyen irányú alakulása alapján feltételezhető, hogy a fitnesz szegmens szolgáltatói is alkalmazkodni fognak ehhez a folyamathoz, és egyre több online elérhető szolgáltatást kínálnak majd a fogyasztóknak. 
AZ ACSM 2021-es trendkutatása is megerősíti ezt a tendenciát, hiszen a világ vezető trendje ebben az évben az online edzés lett, valamint a virtuális edzések is a legmeghatározóbb tíz trend közé kerültek be. Ez a jelentős átalakulás a legnépszerűbb irányzatok között főként a világszerte kialakult járványhelyzet következtében valósulhatott meg. Ezzel összhangban mindenképpen érdemes kihasználni az online edzésekben rejlő lehetőségeket a szegmensben dolgozó szakembereknek, edzőknek is.

A Deloitte 2019-es, valamint Kovács et al. 2015-ös kutatásai alapján az otthoni testmozgás továbbra is a legnépszerűbb helyszínek közé tartozik, és az online platformon hozzáférhető edzések ennek a tendenciának is megfelelnek, hiszen bárhol elérhető sportolási lehetőséget nyújtanak, akár otthoni körülmények között is.

Az edzők körében végzett kutatásunk eredményei azt tükrözik, hogy a fitnesztermek átmeneti bezárása jelentősen átalakította az edzéstartási szokásokat. A lezárások előtt a fitneszedzők jellemzően az edzőtermekben tartották személyi és csoportos edzéseiket, és igen alacsony számban voltak azok, akik szabadtéri helyszínen vagy online felületen kínáltak sportolási lehetőséget. A kialakult járványhelyzet és az azok következtében bevezetett korlátozások óta azonban a mintában leggyakoribb edzéssé az online órák váltak. Ezt követik a kinti helyszínen folytatott edzések, és csak a minta néhány tagja folytatta a zárt helyszíneken az edzéstartást.

$\mathrm{Az}$ online edzések módszereiről mindannyian rendelkeznek ismeretekkel, tehát a lehetséges eszközökről hallottak már, azonban nem mindegyiket alkalmazzák munkájuk során. Az edzők körében legnépszerűbbnek az élő közvetítéses órák valamint az edzős felvételek készítése bizonyult, a fitnesz applikációtól a mintát alkotó edzők idegenkednek a válaszok alapján. Az online órákra való átállást egyértelműen a járványhelyzet tette szükségessé, azonban a válaszadók egy része felfüggesztette edzői munkáját mióta bezárt a fitneszterem, ahol dolgozott.

Ez a helyzet azonban lehetőséget is nyújt az edzőknek a fejlődésre, az innovációra, valamint szolgáltatásainak bővítésére. Az online órák felvételével a repertoárba az edzők vendégkörüket is bővíthetik, hiszen akár az edzések helyszínétől távolabb élők is becsatlakozhatnak, valamint olyan célcsoport is elérhető ezekkel, akiknek egyéb körülmények miatt (például munka vagy gyermek születése) személyesen nem lenne lehetősége megjelenni az órákon.

A publikáció elkészítését a GINOP-2.3.2-15-2016-00005 számú projekt támogatta. A projekt az Európai Unió támogatásával, az Európai Regionális Fejlesztési Alap társfinanszírozásával valósult meg. 


\section{Hivatkozások}

[1] Zopcsák L. (2021) 'A fitnesz szektor aktuális helyzete és jövőképe - nemzetközi kitekintés és hazai körkép' Előadás, Kihívások és trendek a sportgazdaságban - fókuszban a fitnesz szektor online workshop, Debreceni Egyetem, Debrecen.

[2] Jakopánecz E., Törőcsik M. (2018) 'Sportfogyasztásra ható megatrendek trendtanulmány a sport területét befolyásoló fogyasztói magatartásváltozásokról' https://ktk.pte.hu/sites/ktk.pte.hu/files/images/szervezet/intezetek/mti/sport\%20trendek_ta nulmany_2018.pdf

[3] Müller A., Bíró M., Hidvégi P., Váczi P. (2012) 'Fitnesz trendek a rekreációban' Acta Academiae Paedagogicae Agriensis Nova Series: Sectio Sport. 40. 27-36.

[4] Nováky E. (2006) 'Jövőkutatás a változások hálójában' In: Hideg, É., Nováky, E. (szerk.): Jövőkutatás körkép. Tanulmányok a jövőkutatás fényköréből. BCE Jövőkutatás Tanszék, Budapest.

[5] Törőcsik M. (2011) 'Fogyasztói magatartás - Insight, trendek, vásárlók' Akadémiai Kiadó, Budapest.

[6] ACSM (2021) 'ACSM Fitness Trends' https://www.acsm.org/read-research/trending-topicsresource-pages/acsm-fitness-trends. (Letöltés ideje: 2021.04.16.)

[7] Fónai M., Kerülő J., Takács P. (2001) 'Bevezetés az alkalmazott kutatásmódszertanba' Pro Educatione Alapítvány, Nyíregyháza

[8] Kovács A., Paár D., Elbert G., Welker Zs., Stocker M., Ács P. (2015) 'A magyar háztartások sportfogyasztási szokásainak felmérése' Pécsi Tudományegyetem, Pécs.

[9] Bányász P. (2015) 'A közösségi média, mint a nyílt forrású információszerzés fontos területe' Nemzetbiztonsági Szemle, Különlenyomat. 3. (2). Nemzeti Közszolgálati Egyetem, Nemzetbiztonsági Intézet, Budapest.

[10] Feng, J., Xie, W. (2015) 'Digital Divide 2.0: The Role of Social Networking Sites in Seeking Health Information Online From a Longitudinal Perspective' Journal of Health Communication, 20:1, 6068. 